\title{
A critical assessment of how effective the criminal courts are when examining the child
}

\section{Meeka Tomey-Alleyne}

Email: Meeka.Tomey-Alleyne@hotmail.com

\begin{abstract}
The paper suggests that a different approach to the child should be undertaken in the legal system. Children should be viewed as a group who hold their own rights separately to those of the adult and should be acknowledged as underdeveloped in their logic, reasoning and conclusive thinking abilities. If those children were assessed on their own developed abilities, it is argued that the correct administration of justice should ensue.
\end{abstract}

Keywords: Administration of justice; Children's rights; Young offenders; Age of Criminal Responsibility; Criminal proceedings; Criminal liability. 


\section{Introduction}

It is now understood by academics that the development of the child has changed dramatically in the last century. John Locke was inspirational in his evaluation of the child in the beginning of the 1700's. His theory states that the newborn child is a 'Tabula Rosa', meaning an empty state. In his paper he expresses his theory metaphorically arguing:

'[t]he senses at first let in particular ideas, and furnish the yet empty cabinet, and the mind by degrees growing familiar with some of them, they are lodged in the memory, and names got to them. Afterwards, the mind proceeding further, abstracts them, and by degrees learns the use of general names. In this manner the mind comes to be furnished with ideas and language, the materials about which to exercise its discursive faculty."

Following on from John Locke, academics of the 1900's advanced child development theory further. For example, Edward Thorndike presented the 'Law of Effect', which became the basis for operant conditioning within behaviourism. The 'Law of Effect' was based upon the notion that people learn by the consequences of their own acts. iii Operant conditioning research is described as being 'prolific', and is founded on the basis of voluntary behaviours. 'The behaviours arise as a result of the way we operate on our environment and the rewards or punishments that we experience as a consequence. ${ }^{\mathrm{v}}$ Interesting to note is how this can ultimately affect the child in the criminal court system. How might the child act to please an adult? Or, how may the witness spin a truth to help the prosecution? Operant conditioning can teach people and animals to act a certain way within situations, it is controversial but could be fundamental in explaining why the administration of justice may be affected in cases concerning the child. For example, where the single parent asks their young child to put an item in their pocket, in a store, without having paid for said item, and is rewarded later with affection. This would technically be considered as positive reinforcement of socially immoral, and illegal, behaviour.

Albert Bandura has criticised the behaviourist theories as they neglect determinants of man's behaviour arising from his cognitive functioning. ${ }^{\mathrm{vi}}$ The theory could undermine this argument as he states that behaviour is not based purely on imitating others behaviour but rather analysing different behaviours and conceptualising them based on the beliefs and expectations of themselves and others. ${ }^{\text {vii }}$ The analysis the child completes to assess behaviour will be completely dependent upon their environment and background (if we follow Bandura's logic). If said child is surrounded by bad influences, as can be said for the defendants in $R v$ Secretary of State for the Home Department viii can they truly be held accountable for their socially accepted actions? Do they truly know right from wrong?

Whether the child needs to understand right from wrong does not appear to be considered in the Convention on the rights of the Child which gave children, almost worldwide, their own rights; ${ }^{. x}$ this will be considered in further detail later. The recent advances in child development theory have led to 
criticism from the Law Commission ${ }^{x}$ and many others ${ }^{x i}$, as the legal system has not implemented a multidisciplinary, rights-based, approach to the child defendant, or witness, despite many arguments, discussed later, in favour of said approach. It still therefore remains to ask how far can a child be affected by and affect the correct administration of justice?

\section{Children's Rights}

The definition of the child has been internationally accepted to be the United Nations' meaning in the Convention on the Rights of the Child ${ }^{\mathrm{xii}}$ (hereafter $\mathrm{CRC}$ ); this meaning has been ratified by English legislation to the extent of an individual under the age of 18 . The CRC through implementation created a unity amongst the international community, which had never been completed previously; all the countries that agreed to the treaty must provide children with rights and create rights for children. The difference between providing children with rights and creating rights for children can be assessed through Articles 3 and 12. Article 3 states that the 'best interests of the child' shall be considered in all actions concerning children. ${ }^{\text {xii }}$ This creates a right for the child that establishes a rule concerning adults considering their (the child's) best interests. Whereas Article 12 gives children their right to freely express their opinion, should they be developed enough to form and communicate

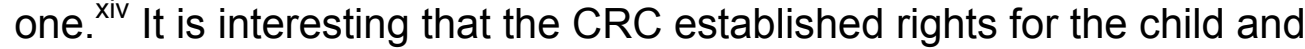
provided rights to the child, as the consequence could be controversial in certain situations; for example where the child believes they should have their opinion considered yet the adult believes they should not.

'The statement that a child has a particular right is both an expression of an existing social norm that recognises the importance of the content of that legal right to the child, as well as a means of changing social norms to be more reflective of that importance. ${ }^{, x v}$

In this instance it could be argued that the social norms, and law in some areas, considered later, need more time for tangible, legally based, changes to happen.

Lucinda Ferguson argues that there are three types of reasons for children's rights: expressive, procedural and substantive. ${ }^{\text {xi }}$ Expressive reasoning relates to empowering the child to ensure their equal respect; but also enfranchises the child to allow them their unique narrative. The second argument stems from procedural reasoning that allows children to make their own decisions. 'A rights-based or children's rights-based approach might secure a greater role for competent children in the decision- making process'

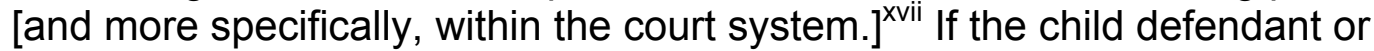
witness was allowed to make his or her own decision how far could the administration of justice be changed? The correct procedural changes could be implemented for said child, making visiting court a less traumatic experience; which is something the Youth Justice and Criminal Evidence Act ${ }^{\text {xviii }}$ has failed to do for child witnesses, and it has since failed in implementing those standards for the child defendant. The third reason for children's rights is based upon substantive reasoning - it is the standard of improvement for the child - in this respect however, it would be aiding the 
child to present the truth so that the correct administration of justice can ensue.

\section{The autonomous child}

'A core dilemma faced by professionals working with children lies in recognising their autonomous rights on the one hand, whilst simultaneously seeking to 'safeguard' or protect them on the other. 'xix 'Autonomy [can be] understood as a minimal capacity - basic autonomy - which signifies the ability to act independently, authoritatively and responsibly. ${ }^{\mathrm{xx}}$ This is something that the child will learn whilst becoming an adult, normally through its peers, parents and from society as a whole. Although, there will always be on the 'one extreme... agents who completely lack autonomy, [whilst on] the other agents who are fully (or ideally) autonomous; in between are agents who exhibit autonomy by different degrees. ${ }^{\text {'xi }}$ It would therefore seem that autonomy is not innate, or possibly that the idea of autonomy is the social construct used to explain and formalise expectations that those peers, parents and society hold. If the child is analysed in a social/psychological context it is viewed that the intellectual competence of a child is underdeveloped whilst the impact of the care from their parents, and social prerequisites that they live by [will them, and they therefore] are interlinked, and consequently cannot be seen as autonomous. ${ }^{x x i i}$

Autonomy is highlighted in the case of $R v$ Wilson. ${ }^{\text {xiii }}$ In this case a 13-yearold boy stated he was 'swept along' by the aggression of his father and helped him kill another. ${ }^{\text {xiv }}$ 'This decision was inevitable, but reflects badly on English criminal law. ${ }^{\text {'xv }}$ The problem with the decision is that an autonomous 13-year-old boy, who is still developing logic and reasoning skills, is under duress to kill, and lacks intent, but is still prosecuted. The Law Commission can be considered to agree with this logic as they stated on the matter:

'capacity to withstand duress is increased with maturity and it would be unjust to expect the same level of maturity from a twelve-year-old as from an adult... a ten-year-old whose moral character is not fully formed should not be expected in all the circumstances to resist the temptation to kill in order to avert a threat to himself. ${ }^{\text {'xxvi }}$

The Court of Appeal did note in their decision the reality is that, on our law as it stands, the appellant did not have a defence' and furthermore that:

'there may be grounds for criticising a principle of law that does not afford a 13-year-old boy any defence to a charge of murder on the ground that he was complying with his father's instructions, which he was too frightened to refuse to disobey. ${ }^{x x v i i}$

The above case highlights ' $[\mathrm{t}$ ]he fallacy that legal values describe physical reality... [put] very simply, the law treats man's conduct as autonomous and willed, not because it is, but because it is desirable to proceed as if it were. 'xxviii This can automatically create an injustice to the child defendant, or even the child witness or victim. It is desirable to the law because: 
'the capacity of the individual human being to live his life in reasonable freedom [from social constraints] would be impaired unless the law provided a locus poenitentiae... [a place of repentance] beyond which external constraints may be imposed, but before which the individual is free...of the very specific constraints of the law.' ${ }^{\text {xxix }}$

Maybe with judicial discretion, the Law Commissions recent reports and the added support of many for raising the minimum age of criminal responsibility (hereafter MACR) we could start seeing tangible changes to the rights based approach the CRC identified.

\section{Consent and the minimum age of criminal responsibility}

For autonomy to be fulfilled by an individual, they must also have the capacity to understand and make their own decisions. 'Hart argues that there is a minimum mental and physical capacity a person must possess if they are to be subjected to criminal liability, which he called "capacity responsibility". ${ }^{x x}$ The concept is also contained within the United Nations Standard Minimum Rules for the Administration of Juvenile Justice. As Rule 4.1 states the age for criminal responsibility 'shall not be fixed at too low an age level, bearing in mind the facts of emotional, mental and intellectual maturity. ${ }^{\text {xxxi }}$ The UK government must adhere to the rule, though because no age limit is directly set it can be argued that they already are adhering. Many other recommendations to raise the MACR have been received including the following: the Centre for Crime and Justice Studies, ${ }^{x x x i i}$ the United Nations Convention on the Rights of the Child's Committee, ${ }^{x x x i i i}$ the Centre for the Prison Reform Trust, ${ }^{x x i v}$ Barnardos, ${ }^{x x x v}$ the Royal Society, ${ }^{x x x v i}$ the Child Rights International Network, ${ }^{x x v i i}$ and the Centre for Social Justice ${ }^{x x x v i i i}-$ there does not appear to be any political will to act on them. ${ }^{\text {xxxix }}$ The Government has repeatedly stated that it has no intention to raise the MACR ${ }^{\mathrm{xl}}$ though Scotland has raised their MACR to $12^{\mathrm{xli}}$ and Northern Ireland have consulted on raising theirs to 12 , with the potential to raise it to 14 .lii $^{\text {Without the }}$ government making changes to the MACR children will continue to be prosecuted without any real logical reasoning. By real it is not argued that the law is not reality, it is argued that a law lacking clear logical reasoning should not be supported by politicians or the judiciary.

In England, '[c]hildren below the age of 10 are considered to be incapable of committing crime as they are deemed unable to form the requisite mens rea.' 'xliii Conversely, the disciplines of sociology and psychology theorise that children are not developed enough to be reprimanded for crimes at age 10. Jean Piaget was fundamental in understanding child development. ${ }^{\text {xliv }} \mathrm{He}$ conceptualised clear stages of development as: 'sensorimotor', 'preoperational', 'concrete operational' and 'formal operational'. The latter stages, concrete operational and formal operational, develop between the ages of 7-16 and are deemed to develop the area of logical thought and the beginnings of abstract reasoning which can help with consequential thinking and judgment. ${ }^{\text {Xlv }}$ Jean Piaget's theory was also criticised as some have stated that not every person makes it to the formal operation stage. ${ }^{x l v i}$ Although the Government are unwilling to raise the age of criminal responsibility it seems clear that the European Union, although not always agreeing to a raise in the 
MACR $^{\text {xlvii }}$, may have changed their mind as the Commissioner for Human Rights stated that:

'[he has] extreme difficulty in accepting that a child of 12 or 13 can be criminally culpable for his actions, in the same sense as an adult. [He does] not mean to deny that extreme measures may need to be taken, both to punish the act and to attempt to correct whatever it is that has clearly gone so drastically wrong.'xlviii

The view taken by the Commissioner is similar to the restorative justice that the UK government reported in its note on the MACR. Their note states:

'We are now seriously considering widening the delivery of restorative justice and giving the police their own restorative justice interventions for the lower level of offences, which could be recorded for their own purposes. That is in addition to making sure that people both make restoration and receive punishment - the two are not alternatives - in the rest of the criminal justice system. ${ }^{\text {xlix }}$

Restorative justice should be used for all, as well as punishment dependent upon severity of the crime committed, between the ages of 10 and 18. English legislation is curious in relation to decision making for children between these ages. The Mental Capacity Act' states that a person will have capacity unless otherwise proven, and section 2 states that a lack of capacity cannot be proven merely by reference to age. 'i Therefore meaning one has the capacity to make decisions. If an individual becomes involved with the Mental Health Act ${ }^{\text {lii }}$ the act will apply to any person at any age. Agreeably, Parents have control over all persons under the age of $18^{\text {liii }}$, yet, one can be married legally, with parental consent, at the age of 16 , without it is at the age of 18 . ${ }^{\text {liv }}$ A child is viewed as competent and capacitated, when under the age of 16 , if they can understand the facts for making decisions in respect of healthcare. This principle was derived from Gillick $v$ West Norfolk and Wisbech Health Authority. ${ }^{\prime}$ Lord Scarman's ratio decidendi was of particular interest as he stated that:

'[t]he principle of the law... is that parental rights are derived from parental duty and exist only so long as they are needed for the protection of the person and property of the child. The principle has been subjected to certain age limits set by statute for certain purposes: and in some cases the courts have declared an age of discretion at which a child acquires before the age of majority the right to make his (or her) own decision.' ${ }^{\text {,vi Ivii }}$

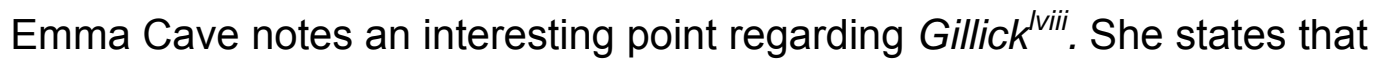
defects in the individual's ability to control her desires or actions, reasoning abilities, the information available to her, and in the stability of the individual's own desires, can impede her [the child's] autonomy. ${ }^{\text {lix }}$ The problem with Cave's analysis is that it tends to create a circular argument: if the child cannot understand then they do not have the adequate capacity to make the choice, and if they do not have capacity then they do not have autonomy, if they do not have the autonomy then they are not in a position to engage with their rights as a child. This would lead to a child not being criminally culpable 
when breaking the law, or a child witness not being able to stand as a witness simply because they are children.

If in some cases the child can be considered to make their own decision, surely a new defence to replace doli incapax should be used as a defence for children. It is argued that the child does not have the typical defences available, however, where the child is provided specific rights, and changes are made to the trial procedure for said child should there not also be a defence available for those who are not as developed as their peers? This was a view taken by the Law Commission. The only defences, which currently could be used for the child's lack of development, are fitness to plead and diminished responsibility. Fitness to plead could be used by the child but it is based around the notion of comprehension and is not sympathetic to the child. The test was founded in $R v$ Pritchard ${ }^{\mathrm{x}}$ and applies to any person who has 'insufficient intellect to instruct his solicitors and counsel, to plead to the indictment, to challenge jurors, to understand the evidence, and to give evidence.'|xi Moreover, the defence of diminished responsibility does not include 'developmental immaturity'. to be flexibility within the law that allows for children who have not developed at the same rate as their peers, ${ }^{\text {Iiii }}$ it could be said that this would be similar to the 'reasonable man' standard. The Law Commission concluded that 'there is an imperative need for a review of the law of homicide in relation to child and young person defendants. ${ }^{\text {,xiv }}$ Dr Eileen Vizard has stated that there must be an appreciation that the child's competence cannot be assessed without reference to the child's developmental status, mental state, family and environment. ${ }^{\mid x v}$ The Law Commission have also accepted that a balance must be undertaken in respect of assessing children based on a rights, decision making position and assessing them in terms of their ability to comprehend right from wrong. ${ }^{\text {Ixi }}$ The unanswered question that the Law Commission and Dr Vizard create is whether defences would be needed if the child were to be assessed? If there was an assessment undertaken of said child defendant, or witness, which culminated in a report stating the child does not have adequate mental capacity to form the mens rea of the offence surely there would be little need for a defence?

The Youth Justice and Criminal Evidence Act 1999 and the child witness It is pertinent at this point to note the recent legislation that has been introduced to aid the child within the court system. The Youth Justice Criminal Evidence Act section (hereafter YJCEA and S) 16 states that 'a witness in criminal proceedings (other than the accused) is eligible for assistance ... if under the age of 17 at the time of hearing." ${ }^{\text {,xvii }}$ The assistance established is that of the special measures directions which will be analysed later. The main provisions regarding witness competence are sections 53-57. The sections state there is a clear presumption of competence for all witnesses exempting only those incapable of making themselves understood; ${ }^{\text {Ixviii }}$ the onus of proving competence is placed upon the party calling the witness, and the hearing of competence is established without the jury present. Ixix If a witness is not sworn, but should have been (any one over the age of 14) then there will be a challenge to the conviction. ${ }^{\mathrm{Ixx}}$ The judge will also have to admonish 
the witness, as endorsed by Judge Auld in Hampshire:Ixxi 'Tell us all you can remember of what happened. Don't make anything up or leave anything out. This is very important. "xxii Furthermore, perjury will be committed if you were lawfully sworn, if you were sworn when you should not have been, then perjury cannot be committed. Ixxiii The main contentious point is that Children's competence in court cannot be assessed without reference to the child's developmental status, mental state and family/environment. ${ }^{\text {Ixxiv }}$ This could lead to an injustice being committed.

The special measures directions (hereafter SMD), mentioned earlier, were implemented to help children give the best evidence they can in court. ${ }^{\text {Ixxv }}$ They are ruled on at the beginning of a trial if there are vulnerable witnesses involved. There are eight SMD's set out in the YJCEA between S23-30. The main ones I shall examine are: evidence by live link, ${ }^{\text {Ixxi }}$ video recorded examination and cross examination ${ }^{\text {Ixvii }}$ and examination through intermediary. Ixxviii Firstly, evidence by live link is available by ruling of a SMD. The child also 'may not give evidence in any other way ${ }^{\text {|lxxix }}$ if specified by the court, though in practice all children now give evidence this way. ${ }^{\operatorname{lxx}} \ln R v$ Redbridge Youth Court Latham LJ stated that 'the impact of evidence given directly to the court is likely to be greater whether it be in favour of the

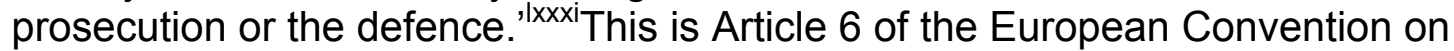
Human Rights (hereafter ECHR) compliant, however, it is 'unfortunate that in formulating an implicit 'equality of arms' rationale, Latham LJ subscribed to the common but untested perception amongst English barristers that evidence on video link is less persuasive for jurors'. Ixxxii It is contrary to the main requirement that quality of their evidence will be improved. ${ }^{\text {Ixxiii }} A$ potential problem with the live link is that a witness should be seen by judge, jury, legal representatives, and anyone helping the witness. If they cannot be seen, it can contravene Article 6, ECHR as the defendant will have been deprived of the right to participate effectively in their trial. Another criticism regarding the live link is that the YJCEA is completely silent as to who can sit in the room with the witness. It is usually a court usher, though, it could be detrimental in allowing the best evidence the witness can give. The point of the live link is to alleviate as much anxiety as possible. Should there be guidance published on the role? It was recommended that 'the Lord Chief Justice review the existing guidelines on the identity of the support person. "Ixxxiv If the person in the room was someone the child knew well such as a parent, the child could feel constrained about any changes to the account that ought to be made. ${ }^{\text {Ixxxv }}$

The Pigot Report was the first to establish a need for video evidence. It states 'almost all of those who submitted evidence to us believed that the existing law is far too restrictive and that some general provision ought now to be made for video recorded evidence to be admissible, ${ }^{\text {, } x \times x v i}$ today this is provided for in the YJCEA. It has been met with some criticism, at first, specifically regarding when new information comes to light in a trial, or when there is a need to re-examine a witness. However, the YJCEA allows for this:

'that the proposed cross-examination is sought by a party to the proceedings as a result of that party having become aware, since the time when the original recording was made in pursuance of subsection (1), of a matter which 
that party could not with reasonable diligence have ascertained by then' or in the course of justice. ${ }^{\mid x x x v i i}$

'The risk that any inconsistencies between statements made in the two recordings would have to be cross-examined on separately, were glossed over by government spokesmen in Parliament. ${ }^{\text {,xxxviii }}$ The defendant must also be able to see and hear the examination and to communicate with his lawyer whilst the judge and advocates must be able to see and hear the examination of the witness and to communicate with the persons in whose presence the recording is being made. Furthermore, a concern is that the defence will be partial as they will have to cross examine in advance of the trial, without hearing any other witnesses examinations. Defence advocates could also feel disadvantaged as a jury will not be present, and, rightly or wrongly, they can generally take a feel to how evidence is sitting with them. A change of a last minute plea to guilty will not save the prosecution witness from having to go through examination, ${ }^{\text {Ixxix }}$ causing more stress for the child.

The third significant point is that relating to the examination through an intermediary. It has been held by the European Commission that $S 29^{\mathrm{xC}}$ would not contravene Art 6 (Baegen v Netherlands. ${ }^{x c i}$ ). S29 (2) goes further than just reiterating questions and answers, but instead explains questions and answers between the court room and witness so that both can be understood. The reiteration of any question would need to be told to the court, however illogical or irrational it may be, without which, a defendant could argue the trial was unfairly conducted and an injustice was done. ${ }^{\text {xcii }}$ It is therefore obvious; an intermediary would need to be competent, impartial, and fully independent. It could create an issue with the child, if they are unwilling to speak through a stranger, or for the intermediary understanding the child may be quite hard. If a situation did occur where the only individual able to act as an intermediary was someone the child knew, then a registered intermediary would have to act on their behalf to evaluate the witness' capacity. More practical problems also arise, as if the witness speaks with the police as part of their investigation of the defendant, the police would need to pre-guess whether the court would use an intermediary. The court would then have to be satisfied that the correct intermediary was used to access the best evidence - as well as the person being completely independent, otherwise the testimony will be contaminated and a challenge to the conviction under Art 6 may become available. ${ }^{\text {xiii }}$

\section{Concluding statements}

The CRC was implemented to improve children's rights and provide children rights. The rights have aided the child, they have given the child the option to participate in decision making processes (whether they are acknowledged or not) and this ultimately should affect the administration of justice in a positive way. ${ }^{\text {xciv }}$ The other argument to this is that the child, dependent upon age, is still developing, how much power, and ultimately responsibility, should they have? It is a balancing act that should be undertaken on a case-by-case basis. The process would slow down trials, but raising the MACR would manage the amount of cases potentially going to trial. 
There is quite obviously a new defence needed to replace the loss of doli incapax, potentially one of 'developmental immaturity,' ${ }^{\text {xc }}$ although that was to be used only when the crime of murder had been committed. 'Developmental immaturity'xcvi, unfortunately does not go far enough to support the child. It would only be available for those who are not as developed as their peers. If the MACR was raised there would be less need for defences such as this. In respect of the SMD's mentioned above, it is argued that the same should be done for the child defendant, and that the child should be seen as a child no matter whether victim, witness or defendant. The Coroner and Justice Act ${ }^{\text {cvvii }}$ created a new provision of intermediary's for child defendants - but does this really meet the expectation which is thwarted in respect of child development and does it really aid the child in the court system?

The criminal law system needs a rights-based approach to the child which is infavour of who the child is and not just what they have done.

\section{Bibliography}

Books:

1. Hart HLA, Punishment and Responsibility: Essays in the Philosophy of Law (Clarendon Press Oxford 1968)

2. Packer $\mathrm{HL}$, The limits of the criminal sanction (Stanford university press 1968)

3. Williams GL, The Criminal Responsibility of Children [1954] Criminal Law Review 493

\section{Cases:}

1. Rex v Pritchard [1886] 173 England Reports 135

2. $R v$ Robertson [1968] 52 Criminal Appeal Reports 690

3. $V$ and $T$ V UK [2000] 30 European Human Rights Reports 121

4. Gillick v West Norfolk and Wisbech Health Authority [1984] Appeals Court 112

5. $R v$ Wilson [2007] England and Wales Court Appeals (Criminal division) 1251

6. R v Hampshire [1996] Queens Bench division 1

7. Kensington and Chelsea Royal London Borough Council v Simmonds [1996] 3 Family division 246

8. $R v$ Camberwell Green Youth Court [2005] House of Lords 4

9. $R$ (Director of Public Prosecutions) v Redbridge Youth Court [2001] High Court (Admin) 209

European Cases:

1. Case C 16696/90 Baegen v Netherlands [1995]

Legislation:

1. Youth Justice and Criminal Evidence Act 1999

2. The Mental Capacity Act 2005

3. The Mental Health Act 1983 and 2007

4. Children Act 1989

5. Coroner and Justice Act 2009 
EU Legislation:

1. The European Convention on Human Rights 1950

Reports:

1. Pigot, the report on the advisory group on video evidence 1987

2. Farrington, D.P. \& West, D Criminal, penal and life histories of chronic offenders: Risk and Protective factors and early identification. Criminal Behaviour and Mental Health [1993]

3. Decisions and Reports of the Commission CommDH (2005) 6

4. Viv Ashley, Philosophical models of Personal Autonomy [2012] The Essex Autonomy Project Green Paper Technical Report

UN Convention:

1. Convention on the Rights of the Child, United Nations Human Rights 1990

2. United Nations Standard Minimum Rules for the Administration of Juvenile Justice 1985

Journal articles:

1. Elliott C, 'Criminal Responsibility and children: a new defence required to acknowledge the absence of capacity and choice' [2011] Journal of Criminal Law

2. Hoyano LCH, 'Striking a balance between the rights of defendants and vulnerable witnesses: will special measures directions contravene guarantees of a fair trial?' [2001] Criminal Law Review

3. McEwan J, 'In defence of vulnerable witnesses: the Youth Justice and Criminal Evidence Act 1999' [2000] International journal of Evidence and Proof

4. Hollingsworth K, 'Theorising Children's Rights in Youth Justice: The Significance of Autonomy and Foundation Rights' [2013] Modern Law Review 1046

5. Ferguson L, 'Not merely rights for children but children's rights: The theory gap and the assumption of the importance of children's rights' [2013] International Journal of Children's rights.

6. Purvis A, 'Doli Incapax: the culpability of children in criminal law Journal of criminal law' [2009] Journal of Criminal law 136

7. Ashworth A, 'Murder: defence - young defendant - intention to kill defendant's father instructing him to assist in murder', [2008] Criminal Law Review 138

8. Cave E, 'Maximisation of minors capacities' [2011] Child and Family Law Quarterly 431

9. Buss E, 'What the Law Should (and Should Not) Learn from Child Development Research' [2009] Hofstra Law Review Vol 38:13

\section{Seminar Series}

1. Vizard E, 'POST/ESRC seminar on Neuroscience, children and the law' (2012) University of Exeter 


\section{Law Commission reports}

1. Law Commission, Partial defences to murder (Law Comm 2004)

2. Law Commission, 'A New Homicide Act for England and Wales?' (LCCP 177 2005)

\footnotetext{
'For example see the works of: I Pavlov, The Experimental Psychology and Psychopathology of Animals (1903) and BF Skinner, Beyond Freedom and Dignity, (Pelican Books 1971) ii J Locke, An Essay Concerning Human Understanding (1690) Ch 1, para 15

iii EL Thorndike, Animal Intellegence: an experimental study of the associative processes in animals (1898)

iv W Vialle, I Verenikina, Handbook on Child Development, (Cengage Learning Australia, 2000) 8

$\checkmark$ IBID 8

${ }^{v i}$ A Bandura, Social learning theory, (General Learning Corporation 1971) 2

vii IBID

viii [1996] 2 WLR 67

${ }^{\text {ix }}$ Convention on the Rights of the Child, United Nations Human Rights 1990

${ }^{x}$ Law Commission, Partial defences to murder (Law Comm 2004) para 3.134

${ }^{x i}$ See points $17-23$

xii Convention on the Rights of the Child, United Nations Human Rights 1990

xiii IBID, Article 3 para 1

xiv IBID, Article 12 para 1

${ }^{x v}$ Lucinda Ferguson, 'Not merely rights for children but children's rights: The theory gap and the assumption of the importance of children's rights' [2013] International Journal of

Children's rights 21 , page 28

xvi IBID 27

xvii IBID 32

xviii Youth Justice and Criminal Evidence Act 1999

${ }^{x i x}$ E Vizard, POST/ESRC seminar on Neuroscience, children and the law (University of
} Exeter 2012)

xx V Ashley 'Philosophical models of Personal Autonomy' [2012] The Essex Autonomy Project Green Paper Technical Report, 1 Page 5

xxi IBID 5

xxii C Elliott, 'Criminal Responsibility and children: a new defence required to acknowledge the absence of capacity and choice' [2011] Journal of Criminal law 289297

${ }_{x x i i i} R \vee$ Wilson [2007] EWCA Crim 1251

xxiv IBID

${ }^{x \times v}$ Andrew Ashworth 'Murder: defence - young defendant - intention to kill - defendant's father instructing him to assist in murder' [2008] Criminal Law Review 138139

xxvi Law Commission, A New Homicide Act for England and Wales? (LCCP 177 2005) Para 7.72

${ }^{x x v i i} R v$ Wilson [2007] England and Wales Court of Appeal Criminal division 125, page 420

xxviii HL Packer, The limits of the criminal sanction, (Stanford university press 1968) 74

xxix IBID 75

${ }^{x x x}$ HLA Hart, Punishment and Responsibility: Essays in the Philosophy of Law (Clarendon Press 1968); C Elliott 'Criminal Responsibility and children: a new defence required to acknowledge the absence of capacity and choice' [2011] Journal of Criminal law 289294 xxxi United Nations Standard Minimum Rules for the Administration of Juvenile Justice 1985 xxxii 2006

xxxiii 2002 and 2007

xxxiv 2009

${ }^{x x x v} 2010$

xxxvi 2011

xxxvii 2012

xxxviii 2012 
${ }^{x x x i x}$ E Vizard, 'POST/ESRC seminar on Neuroscience, children and the law' [2012] University of Exeter

${ }^{x}$ See for example HL Deb 20 December 2010 c 815-7, HC Deb 20 July 2011 c 1107-8W and HC Deb 11 August 2011 c 1086

xii Criminal Justice and Licensing (Scotland) Act 2010, S52

xlii Department of Justice, A Review of the Youth Justice System in Northern Ireland, 2011, section 5.6

xliii Amy Purvis, 'Doli Incapax: the culpability of children in criminal law' [2009] Journal of Criminal law 136137

xliv See for example, Jean Piaget's theories on child development, 'The Moral Judgement of the Child' (1932), 'Origins of Intelligence in the Child' (1936), 'Play, Dreams and Imitation in Childhood' (1945)

${ }^{x / v}$ E Vizard, 'POST/ESRC seminar on Neuroscience, children and the law' [2012] University of Exeter

xlvi See for example the books of $\mathrm{P}$ Dasen Culture and cognitive development from a Piagetian perspective (Allyn and Bacon 1994) and D Keating Handbook of Adolescent psychology (Jon Wiley and Sons Inc 2004)

xlvii it was noted in $V$ and T V UK [2000] 30 EHRR 121, that '[a]lthough in most of the Member States criminal responsibility would not be attributed to a child of 10 , there is no common approach to the attribution of criminal responsibility.'

xiviii Decisions and Reports of the Commission CommDH (2005) 6

xlix The age of criminal responsibility in England and Wales, Standard Note [2012]

' [2005]

"Ii IBID, S2 (3)(a)

lii Mental Health Act 1983 and 2007

liii Children Act 1989, Section 1

liv Marriage Act 1949 S3

${ }^{\text {IV }}$ [1984] AC 112

Ivi IBID 184

Ivii IBID 184

Iviii IBID

lix E Cave, 'Maximisation of minors capacities' [2011] Child and Family Law Quarterly, Vol 23, No 4, 431434

${ }^{\mathrm{Ix}}$ Rex $\mathrm{v}$ Pritchard [1886] 173 ER 135

${ }^{1 \times i} R$ v Robertson [1968] $52 \mathrm{Cr}$ App R 690

Ixii Law Commission, Partial defences to murder (Law Comm 2004) para 3.134

Ixiii IBID

Ixiv IBID

${ }^{\mathrm{x} V} \mathrm{E}$ Vizard, 'POST/ESRC seminar on Neuroscience, children and the law' (2012) University of Exeter

Ixvi Law Commission, Partial defences to murder (Law Comm 2004) para 3.133

Ixvii Youth Justice and Criminal Evidence Act 1999 s 16(1)(a)

Ixviii Youth Justice and Criminal Evidence Act 1999 s 53

xix Youth Justice and Criminal Evidence Act 1999 s 54

${ }^{1 \times x}$ Youth Justice and Criminal Evidence Act 1999 s 54

${ }^{\mathrm{I} \times \mathrm{i}} R$ v Hampshire [1996] QB 1

Ixxii IBID

Ixxiii Kensington and Chelsea Royal London Borough Council v Simmonds [1996] 3 Fam Cr 246

Ixxiv E Vizard, 'POST/ESRC seminar on Neuroscience, children and the law' (2012) University of Exeter

${ }^{1 \times x v} R$ v Camberwell Green Youth Court [2005] UKHL 4

Ixxvi Youth Justice and Criminal Evidence Act 1999 S 24

Ixxvii IBID s 28

Ixxviii IBID s 29

Ixxix Youth Justice and Criminal Evidence Act 1999 S 24 (2)

${ }^{I x x x}$ Laura C.H. Hoyano, 'Striking a balance between the rights of defendants and vulnerable witnesses: will special measures directions contravene guarantees of a fair trial?' 2001

Criminal Law Review 964, page 949 
${ }^{1 \times x \times i} R$ (Director of Public Prosecutions) $v$ Redbridge Youth Court [2001] EWHC 209

Ixxxii LCH Hoyano, 'Striking a balance between the rights of defendants and vulnerable

witnesses: will special measures directions contravene guarantees of a fair trial?' 2001 Crim LR 962, page 963

Ixxxiii J McEwan, 'In defence of vulnerable witnesses: the Youth Justice and Criminal Evidence Act 1999' 2000 International journal of evidence and proof 1, 6

Ixxxiv IBID 6

Ixxxv IBID 6

Ixxxvi Pigot, the report on the advisory group on video evidence 1987 para 2.9

Ixxxvii Youth Justice and Criminal Evidence Act 1999 S 28 (6)(a)(b)

Ixxxviii J McEwan, 'In defence of vulnerable witnesses: the Youth Justice and Criminal Evidence Act 1999' [2000] International journal of evidence and proof 1, 9

Ixxix IBID 10

${ }^{x c}$ Youth Justice and Criminal Evidence Act 1999 s 29

${ }^{x c i}$ Case C 16696/90 Baegen v Netherlands [1995]

xcii Article 6, European convention on Human rights 1950

xciii LCH Hoyano, 'Striking a balance between the rights of defendants and vulnerable witnesses: will special measures directions contravene guarantees of a fair trial?' 2001

Criminal Law Review 948, 966

${ }_{x c i v}$ Convention on the Rights of the Child, United Nations Human Rights 1990

xcv Law Commission, Partial defences to murder (Law Comm 2004) para 3.134

xcvi IBID

xcvii 2009 